\title{
豚より分離せるパラチフスC型菌に就て
}

宮川文 雄

(阙山残科大學粗菌學教空 主任：鈴木教授)

\section{ON THE BACTERIA OF PARATYPHOID C GROUP ISOLATED FROM SWINE.}

\section{F. MIYAKaWA,}

(From the Laboratories of Bacteriology, Okayama Meti al College. Chief : Prof. Suzu i]

\section{緒}

\section{官}

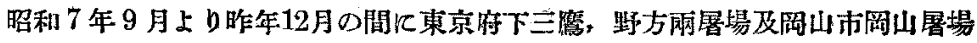

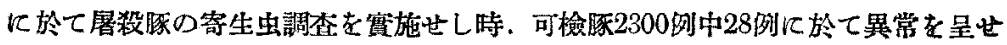

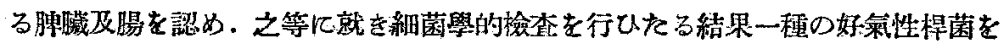

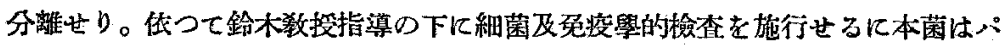
ラチフスC型菌交るを碓め得をり。

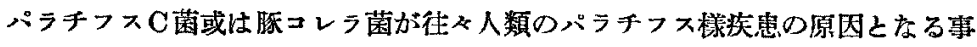

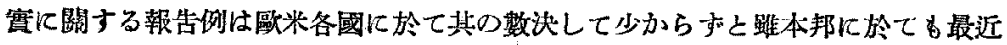
之に關する報告續出するに至れり。師ち我が國に於て患者より本菌を墢胃せるは

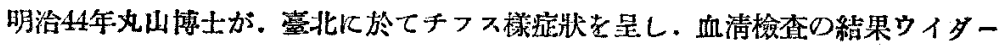

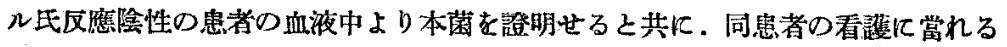
母親の尿中よりバラチフスA，B型に屬せさる類蜀菌を發見し、林氏之を精查し $\tau$ Hirsehfeld の Paratyphus C 型菌なる事を確めたり。次で瀧田，藤井氏等は涩

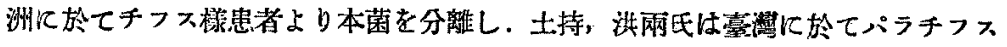

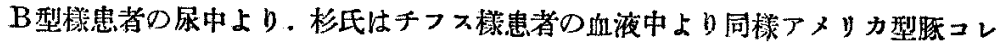

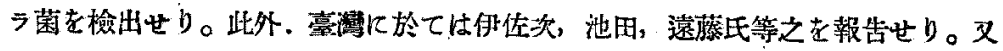




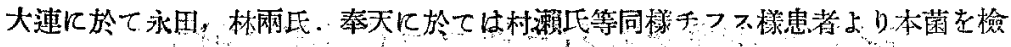
出せるを報告せり。本邦內地に於ては昭和 8 年寺邑, 松本兩氏東京に於てチフス

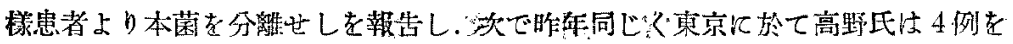
舉げ之に就て詳細なる研究埌告考なした。

斯の如くパラチフス、C菌は人體のチフス樣疾患の原因として報告せられし外. 本菌は豚のパラチフス痕の原因として最近本邦に於て寺門，能美兩氏の超告あ

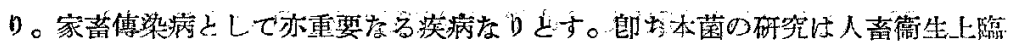
床上及び細菌學上極めて興味ある事填索り之思料せらるるるのり。

\section{生物學的性狀}

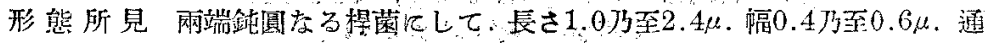

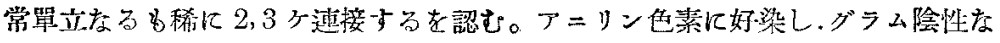

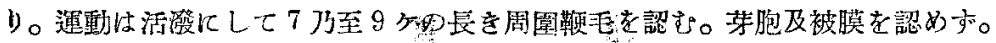

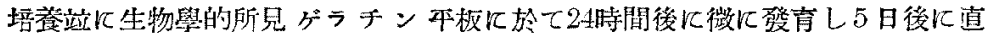

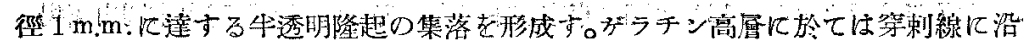

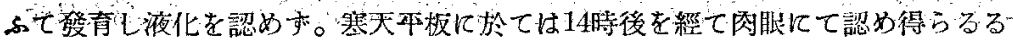

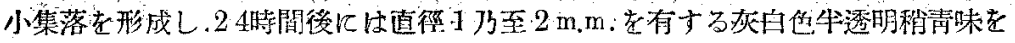

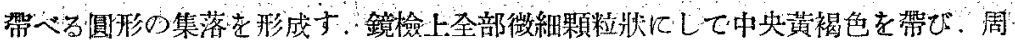

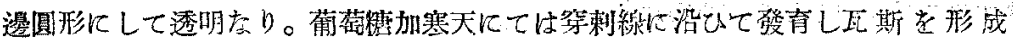

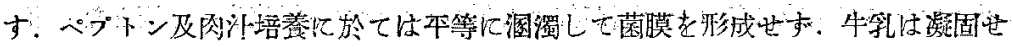

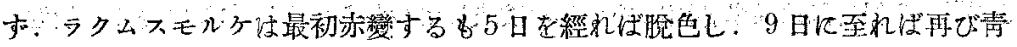

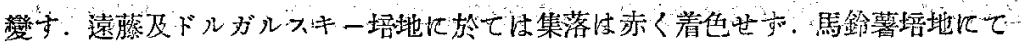

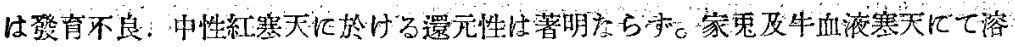

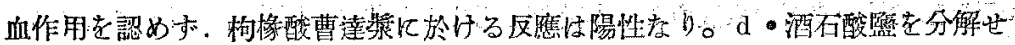

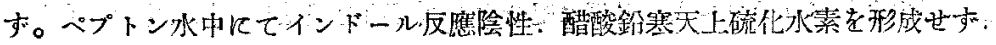

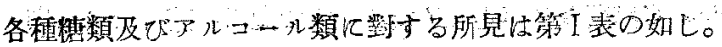

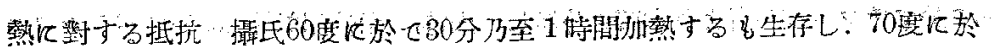

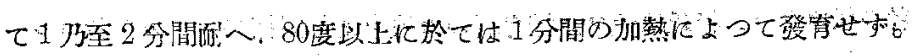

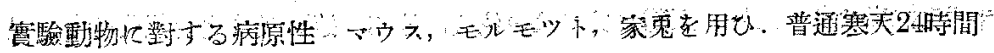


第 I 表

\begin{tabular}{|c|c|c|c|c|c|c|c|c|c|c|c|c|c|c|c|c|c|}
\hline 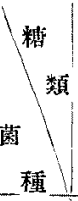 & $\begin{array}{l}> \\
2 \\
= \\
y \\
1\end{array}$ & $\begin{array}{l}3 \\
7 \\
1 \\
1 \\
1 \\
\text { t" }\end{array}$ & $\begin{array}{l}\gamma \\
F \\
= \\
y \\
F\end{array}$ & $\begin{array}{l}t^{\prime} \\
\text { j } \\
\text { ' } \\
\text { t゙ }\end{array}$ & $\begin{array}{l}\neq \\
\dot{y} \\
\square \\
1 \\
1 \\
+\end{array}$ & $\begin{array}{l}\text { H } \\
7 \\
\eta \\
1 \\
1 \\
\text { Ł゙ }\end{array}$ & $\begin{array}{l}\vec{F}^{*} \\
\neq \\
x \\
1 \\
\square \\
1 \\
t^{\prime}\end{array}$ & $\begin{array}{l}V \\
7 ゙ \\
0 \\
1 \\
\text { t }\end{array}$ & $\mid \begin{array}{l}y \\
x \\
6 \\
y \\
1\end{array}$ & $\mid \begin{array}{l}20 \\
2 \\
3 \\
1 \\
k\end{array}$ & $\begin{array}{l}1 \\
z \\
z \\
y \\
1\end{array}$ & $\begin{array}{l}x \\
n \\
+ \\
y \\
r\end{array}$ & $\mid \begin{array}{l}1 \\
\times \\
1 \\
2\end{array}$ & $\mid \begin{array}{c}7 \\
7 \\
x \\
1 \\
y \\
2\end{array}$ & $\mid$\begin{tabular}{c|}
$\#$ \\
$y$ \\
7 \\
$a$ \\
1 \\
$t$
\end{tabular} & $\begin{array}{l}\nabla \\
N \\
1 \\
1 \\
\text { t }\end{array}$ & $\begin{array}{l}1 \\
1 \\
\text { tw }\end{array}$ \\
\hline $\begin{array}{l}\text { 分 } \\
\text { 雄 } \\
\text { 菌 }\end{array}$ & $\begin{array}{l}+ \\
+\end{array}$ & - & - & - & + & - & $\begin{array}{l}+ \\
+\end{array}$ & $\begin{array}{l}+ \\
+\end{array}$ & $\begin{array}{l}+ \\
+\end{array}$ & $\begin{array}{l}- \\
-\end{array}$ & $\begin{array}{l}- \\
-\end{array}$ & - & - & $\mid \begin{array}{l}- \\
-\end{array}$ & - & $\begin{array}{l}+ \\
+\end{array}$ & - \\
\hline $\begin{array}{l}7 \\
7 \\
x \\
\text { 菌 }\end{array}$ & $\begin{array}{l}+ \\
+\end{array}$ & - & - & + & + & - & + & $\begin{array}{l}+ \\
+\end{array}$ & + & ! & - & - & $\begin{array}{l}- \\
-\end{array}$ & $\begin{array}{l}- \\
-\end{array}$ & - & $\begin{array}{l}+ \\
+\end{array}$ & - \\
\hline 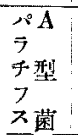 & + & - & - & + & - & -- & + & $1+$ & + & - & - & + & - & - & - & + & - \\
\hline $\begin{array}{l}\text { B } \\
\mathbf{5} \\
\text { 千型 } \\
\text { ス菌 }\end{array}$ & + & - & - & + & + & - & + & + & $\begin{array}{l}+ \\
+\end{array}$ & - & $\begin{array}{l}+ \\
+\end{array}$ & $\begin{array}{l}+ \\
+\end{array}$ & - & $\mid \begin{array}{l}- \\
-\end{array}$ & - & + & - \\
\hline 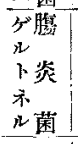 & + & - & - & + & + & - & + & + & + & - & - & $\left\{\begin{array}{l}+ \\
+\end{array}\right.$ & - & $\begin{array}{l}- \\
-\end{array}$ & - & + & - \\
\hline $\begin{array}{c}\text { 䮙流 } \\
\text { 㗋 } \\
\text { 菌 }\end{array}$ & + & - & - & + & $\begin{array}{l}+ \\
+\end{array}$ & - & + & + & & - & -1 & $1+$ & - & $\begin{array}{l}- \\
-\end{array}$ & $\begin{array}{l}- \\
-\end{array}$ & $\begin{array}{l}+ \\
+\end{array}$ & - \\
\hline 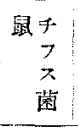 & + & - & - & + & + & - & + & + & $\begin{array}{l}+ \\
+\end{array}$ & - & - & + & - & - & - & $\begin{array}{l}+ \\
+\end{array}$ & - \\
\hline 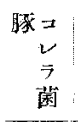 & $\begin{array}{l}+ \\
+\end{array}$ & - & - & - & $\begin{array}{l}+ \\
+\end{array}$ & - & + & + & $\begin{array}{l}+ \\
+\end{array}$ & - & - & - & - & $\begin{array}{l}- \\
-\end{array}$ & $\begin{array}{l}- \\
-\end{array}$ & $\begin{array}{l}+ \\
+\end{array}$ & - \\
\hline
\end{tabular}

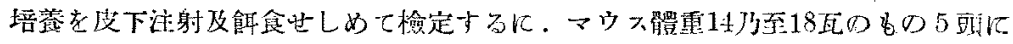

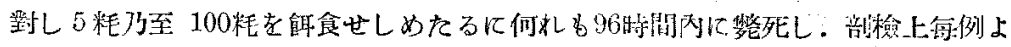

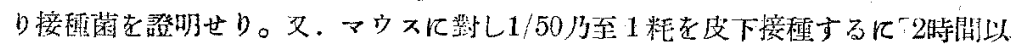
內に全部整死し、剖檢上何れ上りも接種菌を證明せり。モルモツトは 200 亿前後 


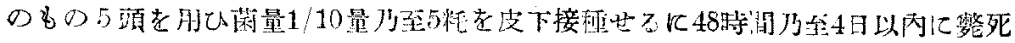

筆 II 涪

\begin{tabular}{|c|c|c|c|c|c|c|c|}
\hline 區 & 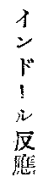 & 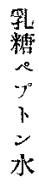 & $\begin{array}{l}\text { 粴 } \\
\text { 寒 }\end{array}$ & $\begin{array}{l}\text { 中 } \\
\text { 性 } \\
\text { 赤 } \\
\text { 然 } \\
\text { 天 }\end{array}$ & $\begin{array}{l}7 \\
\Rightarrow \\
2 \\
2 \\
x \\
z \\
n \\
3\end{array}$ & 学保 & 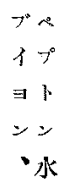 \\
\hline 績 & 㓌 & $\begin{array}{l}\text { 酸 } \\
\text { 形 } \\
\text { 成 } \\
\text { +5 } \\
\text { 2 }\end{array}$ & $\begin{array}{l}\text { 瓦 } \\
\text { 斯 } \\
\text { 形 } \\
\text { 成 } \\
\text { 絮 }\end{array}$ & $\begin{array}{l}\text { 澴 } \\
\text { 元 } \\
\text { 不 } \\
\text { 著 } \\
\text { 朋 }\end{array}$ & 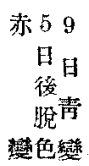 & $\begin{array}{l}\text { 凝 } \\
\text { 固 }\end{array}$ & 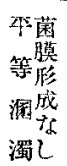 \\
\hline
\end{tabular}

L. 剖检上接和菌学證 明せり。家电は體重 2 率前後のbの5嘼在用 U. 菌翼 1 粍乃至 10 粍 老伩下に接程せるるに。 5 籷以上を接型せる家

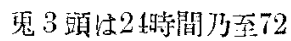
時周以队江梦死し。何 引 6 剖检上接程藏在證

明世口。

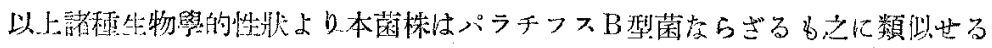

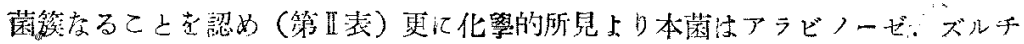

第 JII 表

\begin{tabular}{|c|c|c|c|c|c|c|c|c|}
\hline $\begin{array}{l}\text { 籃 } \\
\text { 別 } \\
\text { 方 } \\
\text { 法 }\end{array}$ & $\begin{array}{l}\text { 葡 } \\
\text { 萄 } \\
\text { 精 } \\
\text { 无 } \\
\text { 踥 }\end{array}$ & $\begin{array}{l}1 \\
> \\
z \\
y \\
1\end{array}$ & $\begin{array}{l}> \\
\overline{7} \\
匕^{\prime} \\
> \\
\text { । } \\
\text { ゼ }\end{array}$ & $\begin{array}{l}\% \\
2 \\
\dot{y} \\
w \\
1\end{array}$ & 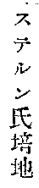 & 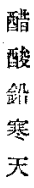 & 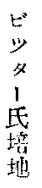 & 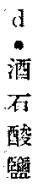 \\
\hline 分 離 䒩 & + & - & - & - & - & + & - & - \\
\hline Typhod & - & - & - & - & - & + & - & - \\
\hline Para $\mathrm{K}$. & \pm & \pm & - & - & - & - & - & - \\
\hline Para A. & + & - & + & - & - & - & - & - \\
\hline Sehotmüller & + & + & + & \pm & + & + & - & - \\
\hline Breslau & + & + & + & + & + & + & + & + \\
\hline Suipest Aner. & + & - & -- & - & - & + & - & - \\
\hline $\begin{array}{l}\text { Para } \mathrm{C} \\
\quad \text { Kunzend. }\end{array}$ & + & - & - & - & - & + & - & - \\
\hline Gïrtner I'. & + & - & + & - & - & + & - & - \\
\hline$"$ I. & + & - & + & + & + & + & + & + \\
\hline
\end{tabular}




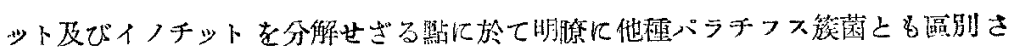

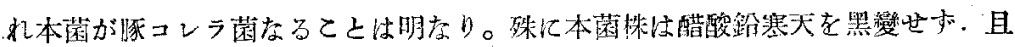

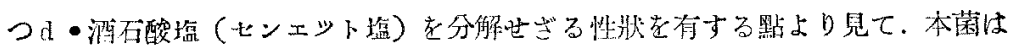

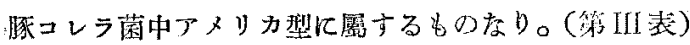

\section{叒疫學的性狀}

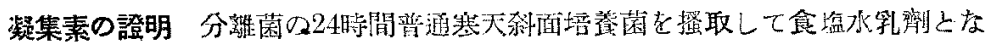

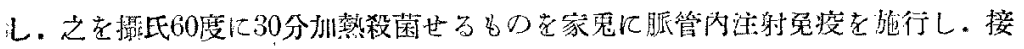
第 IV 表

\begin{tabular}{|c|c|c|c|c|c|c|c|c|c|c|}
\hline 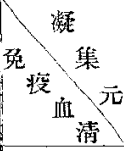 & $\begin{array}{l}\text { 分 } \\
\text { 茈 } \\
\text { 萑 }\end{array}$ & \begin{tabular}{l|l}
$f$ & \\
7 & \\
$\pi$ & \\
菌
\end{tabular} & 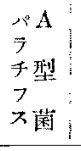 & $\begin{array}{l}\text { パB } \\
7 \\
\text { 手型 } \\
\text { フ } \\
\text { ㅈ藏 }\end{array}$ & 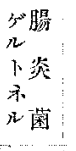 & 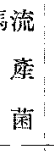 & $\begin{array}{c}\text { 豚 } \\
2 \\
5 \\
\text { 菌 }\end{array}$ & $\begin{array}{c}\text { 鼠千 } \\
7 \\
x \\
\text { 菌 }\end{array}$ & 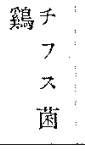 & 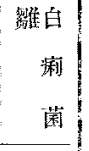 \\
\hline 分離菌 & $12,800^{\circ}$ & 50 & $.50^{\circ}$ & $50^{\circ}$ & - & 501 & 2,800 & 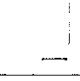 & 50 & 50 \\
\hline チフス闻 & $\rightarrow 1$ & 12,800 & 200 & 50 & 200 & 50 & 50 & 501 & 12,8001 & 12,800 \\
\hline 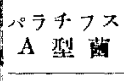 & $\ldots$ & $\underline{1}, 600$ & 6.400 & 50 & 50 & 50 & 100 & - & 100 & $300^{\circ}$ \\
\hline $\begin{array}{l}\text { アラォフ } \\
\text { B 梨菌 }\end{array}$ & $\ldots$ & 50 & & 2,800 & & 50 & & 400 & 200 & $100^{\prime}$ \\
\hline 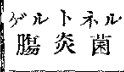 & -1 & 50 & 100 & 50 & 6,400 & 50 & & 6,200 & - & \\
\hline 流黄 菌 & -- & 50 & 100 & 50 & - &, 400 & & 50 & 二 & \\
\hline $\begin{array}{l}\text { 豚 } \\
\pm \\
\pm\end{array}$ & 12,800 & - & 100 & $\rightarrow$ & - & - & 12,800 & - & - & -4 \\
\hline$\stackrel{\text { 鼠 }}{*}$ ス葋 & $\longrightarrow$ & 50 & - & -1 & 6,400 & - & & $\begin{array}{r}\text { ! } \\
12,800\end{array}$ & 50 & 50 \\
\hline 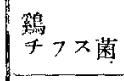 & 80 & 6,400 & 50 & 100 & 100 & 50 & 50 & 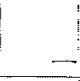 & 12,800 & 12,800 \\
\hline 蜍 & 50 & 6,400 & 100 & 50 & 50 & 50 & 50 & 50 & 12,800 & 12,800 \\
\hline
\end{tabular}

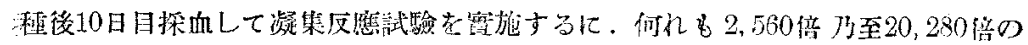
凝集價を現はせるを認めたり。 


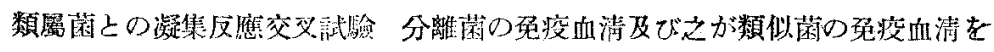

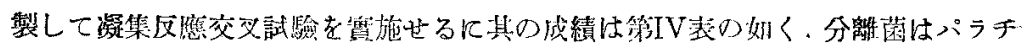

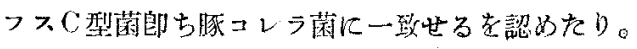

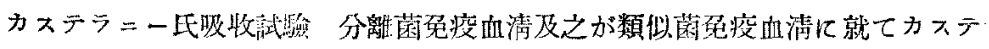

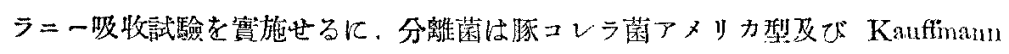

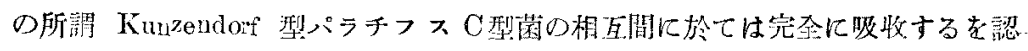

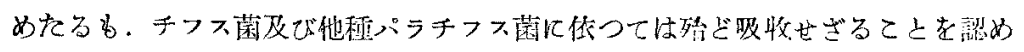
たり。

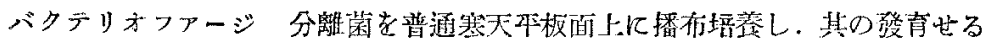
個々の集落に就て Spezifische Phase, Unspezifische Phase の有無老調湘するに分 催菌は Diphasische なるとと老磷め得をり。

\section{總括 及考察}

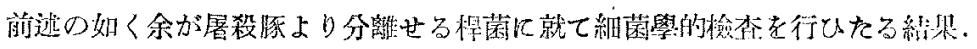

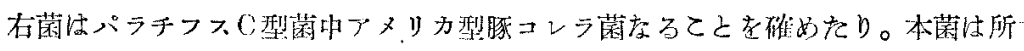

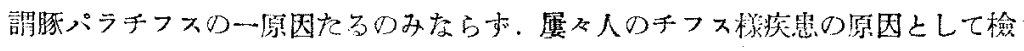

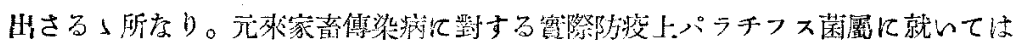

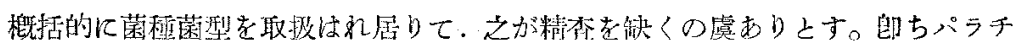

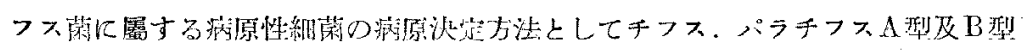

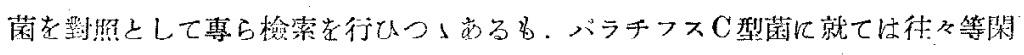

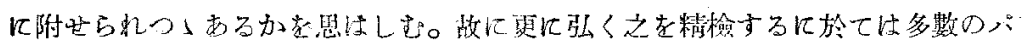

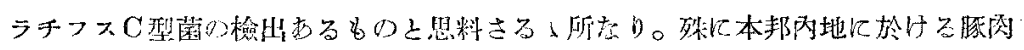

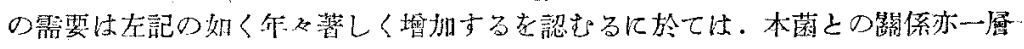

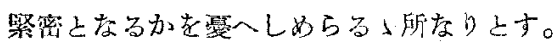

明治40年 157,624 頭

大亚 5 年 250,821 㨁

大正15年 $\quad 574,948$ 激

昭利 9 年 938,410 頭

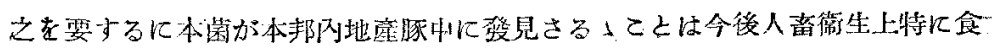




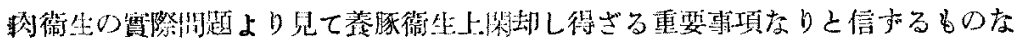
b。

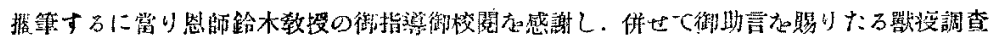

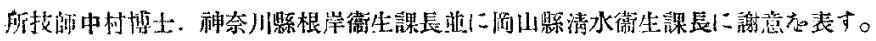

\section{文獻}

(1) Kauffmann : Zbl. Bakt., I, Orig., 119, 152, (i980).

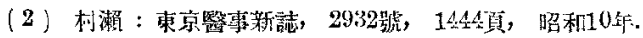

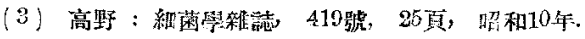

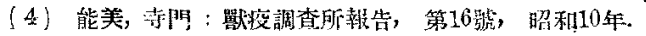

